\title{
Alessandro Benati \\ The effects of re-exposure to instruction and the use of discourse-level interpretation tasks on processing instruction and the Japanese passive
}

\begin{abstract}
This experimental study explores immediate and re-exposure effects of processing instruction on the acquisition of Japanese passive forms as measured by sentence-level and discourse-level tasks. The passive construction in Japanese is affected by learners' use of the First Noun Strategy. Participants were English native speakers and were randomly assigned to one of three groups (processing instruction, processing instruction and re-exposure, and one control group), with the aim of measuring discourse-level and re-exposure effects. Two sentence-level tasks (interpretation and production), and one discourse level task (interpretation) were used in this experiment. The main findings from the study show that L2 learners receiving processing instruction not only improved in their ability to interpret and produce the target feature at sentence level, but they can also use the target forms to interpret discourse. Learners receiving re-exposure to the processing instruction treatment further improve their performance on both sentence-level and discourse-level tasks in an immediate and delayed post-tests battery.
\end{abstract}

Keywords: processing instruction, re-exposure, discourse-level tasks

DOI 10.1515/iral-2015-0007

\section{Introduction}

\subsection{Processing instruction}

Processing instruction is a pedagogical intervention to grammar instruction based on VanPatten's input processing model (VanPatten, 1996, 2004, 2007, forthcoming). The main goal of processing instruction is "to alter the processing

Alessandro Benati: Department of Literature, University of Greenwich, Language and Theatre Greenwich Campus, SE10 9LS, UK. E-mail: A.Benati@gre.ac.uk 
strategies that leaners take to the task of comprehension and to encourage them to make better form-meaning connections than they would if left to their own devices (VanPatten 1996: 60). The effects of processing instruction have been compared to other instructional interventions (e.g., traditional instruction, meaning output-based instruction, dictogloss tasks, and input enhancement techniques). Overall, the results from these studies have shown that processing instruction is an effective pedagogical intervention at helping learners to process grammatical forms and structures affected by processing problems (Lee and Benati 2009). The research database on processing instruction includes learners from a variety of first languages (Chinese, English, Italian, Korean, Japanese) and age groups (adults and school-age learners), covers different languages (English, French, German, Italian, Japanese, German, Arabic and Spanish) and different language families, and it addresses a variety of linguistic forms and structures (e.g. verbal and nominal morphology, passive forms, word order, etc.), thereby addressing different processing problems. However, despite the large database in support of processing instruction, the existing experimental research relies quite heavily on discrete-point sentence-level interpretation and production tasks in establishing the effectiveness of processing instruction. In these studies, participant's performance has mainly been measured by interpretation and production tasks that require learners to perform at the sentence level. That is, learners hear isolated sentences and interpret the meaning of the target linguistic item. They read sentences in which they must supply the correct form of the target linguistic item.

The overall findings of these classroom studies have indicated that participants receiving processing instruction improve their language performance on sentence-level tasks for both interpretation and production. As argued by Dekeyser, Salaberry, Robinson and Harrington (2002) any true system wide effects will be revealed more clearly in the discursive-level tasks and not sentence-level tasks.

\subsection{Previous research on discourse-level effects}

Only a few studies have measured the effects of processing instruction by utilizing tasks that require learners to produce connected discourse, be it oral or written. A few studies have demonstrated that processing instruction is effective at improving L2 learner's performance on discourse-based production tasks (see VanPatten and Sanz, 1995; Sanz 1997, 2004; Cheng, 2002, 2004; Benati, Lee and McNulty 2010). Nevertheless, as highlighted by Lee (2004: 319) in his review of the research on processing instruction, "one limit in the database is absence 
of discourse-level interpretation tasks that might confirm the broader effects of PI on interpretation [...]. How effective is processing instruction for improving learners' performance not only on sentence- but also on discourse-level interpretation tasks?" Benati and Lee (2008: 173) more generally address this as "The Discourse Hypothesis: PI will yield significant improvement on discourse-level tasks."

Benati and Lee (2010) examined discourse-level interpretation effects for processing instruction on the acquisition of English past tense. The discourse-level interpretation task required L2 learners to interpret past tense markers for verbs that were embedded in a dialogue. Benati, Lee and Hikima (2010) also examined the effects of processing instruction on the acquisition of passive construction forms in Japanese on discourse-level interpretations tasks (dialogue and storyguided recall).

Overall the results showed that receiving processing instruction is an effective pedagogical intervention in enhancing learners' interpretation of a target form when it is embedded in discourse. The effects of processing instruction seem to extend to discourse-level interpretation measures, as L2 learners improved from the pre-test to immediate post-tests. Despite the results obtained in these studies more research is needed to address the effects of processing instruction on different grammatical forms and syntactical structures of romance and nonromance languages embedded in discourse.

\subsection{Previous research on durative effects}

Processing instruction research has used pre-test and post-test designs to measure the durative effects of instruction. It has addressed the question of whether the effects of processing instruction endure, diminish or disappear over time. Overall the results of these studies showed that there are short-term durative effects for sentence-level tasks (VanPatten and Cadierno 1993; Cadierno 1995; Benati, 2001, 2004; Farley, 2001, 2004; Cheng 2002; Morgan-Short 2006; Lee and Benati 2007). Learners in processing instruction groups tend to maintain their improved performance (from the pre-test to the immediate post-test) from immediate post-tests to delayed post-tests up to one month from the original instructional exposure. However, their performance dos not seem to improve from immediate post-tests to delayed post-tests and diminish in the longer term (VanPatten and Fernandez 2004). Would repeated exposures to processing instruction be the solution to not only maintain but also increase learners' performance? From a cognitive perspective, repeated exposure may permit L2 learners to strengthen their cognitive understanding of the grammatical structures and foster second 
language acquisition (Anderson 1985). White, Spada, Lightbown and Ranta (1991) conducted a study investigating the effects of re-exposure. The group who received a follow-up treatment one week after the original treatment outperformed the other groups in both immediate and delayed post-test. Leow (1998) investigated the positive effects of re-exposure on L2 learners' ability to interpret and produce morphological forms in Spanish. A single exposure group was compared to a re-exposure group. The re-exposure group received the additional treatment between the immediate post-test and the delayed post-test. The main findings from this study revealed that learners in the re-exposure group maintained and improved their performance from the first to the second post-test.

\subsection{The current study}

The present study aims at measuring immediate and the re-exposure effects of processing instruction using sentence-level (interpretation and production) and discourse-level (interpretation) tasks on the acquisition of Japanese passive construction. Data were collected to provide new evidence to the hypothesis that L2 learners not only cannot maintain but also strengthen their ability to interpret and produce the target linguistic item at sentence-level and interpret the same feature at discourse level if they are re-exposed to the processing instruction treatment. Providing evidence on the relative effects of processing instruction on discourse-level tasks will also offer further support on the effectiveness of this pedagogical intervention on a different language and syntactic feature. Based on previous research, the aim of this study is to explore re-exposure and discourse-level effects of processing instruction on the acquisition of Japanese passive.

\subsection{Research questions}

The following research questions guided the study:

1. Would learners receiving processing instruction improve in their ability to interpret and produce sentences containing Japanese passive forms?

2. Would learners receiving processing instruction improve in their ability to interpret Japanese passive forms embedded in discourse?

3. Would learners receiving re-exposure to the processing instruction treatment between the immediate and the delayed post-tests further improve in their ability to interpret (sentence and discourse) and produce sentences containing Japanese passive forms? 


\section{Methodology}

\subsection{Participants}

Participants were all English native speakers and they were learning Japanese as part of their second year undergraduate degree in a University in the United Kingdom. None were native speakers of Japanese nor bilingual in Japanese. Additionally, none indicated that they had been taught the target form or had been exposed to it previously, in or out of the classroom. The initial subject pool (seventy-two) was reduced (fifty-five) due to several factors. Not all learners agreed to participate in the study so the final data pool consists of only those who signed the consent form and were present for the pre-tests, treatment and posttests. Only subjects who were not taught the target linguistic feature before the experiment were included in the final pool. Only subjects who scored less than $60 \%$ on the three pre-tests (one sentence-level and one discourse-level interpretation task, and one sentence-level production task), were included in the final pool. In the experiment, participants were randomly assigned to three groups after the pre-test phase. The final subject pool consisted of fifty-five participants: processing instruction $(n=20)$; processing instruction-re-exposure $(n=17)$; and control group $(n=18)$.

\subsection{Procedures}

In order to address the research questions, one experimental study was conducted to investigate the effects of processing instruction on Japanese passive forms measured by sentence (interpretation and production) and discourse level interpretation tasks. Possible effects of re-exposing learners to processing instruction were examined. More specifically, it measured whether learners receiving additional training on processing instruction between the first post-test and the delayed post-test, improved in their abilities to interpret and produce the target linguistic item at sentence and discourse levels. The processing instruction group (PI) was taught the targeted linguistic feature through full processing instruction. However this group did not receive the re-exposure treatment. An additional control group was used in this case as the re-exposure treatment was measured. The processing instruction-re-exposure group (PI-R) received the first round of processing instruction and the re-exposure treatment (2 additional hours). The first round of processing instruction treatment consisted of three hours. The control group did not receive any instruction on the target feature but was exposed to a 


\begin{tabular}{|l|l|}
\hline Pre-tests & $\begin{array}{l}\text { Interpretation (sentence and discourse level) } \\
\text { Production (sentence level) } \\
\text { 2 days before treatment }\end{array}$ \\
\hline Treatments & $\begin{array}{l}\text { Processing Instruction group } \\
\text { Control group 1 (processing instruction) } \\
\text { Control group 2 } \\
1 \text { day (3 hours) }\end{array}$ \\
\hline Post-tests & $\begin{array}{l}\text { Interpretation (sentence and discourse level) } \\
\text { Production (sentence level) } \\
\text { Immediate after treatment }\end{array}$ \\
\hline Re-exposure & $\begin{array}{l}\text { Processing Instruction group } \\
\text { Control group 1 (no PI treatment this time) } \\
\text { Control group } \\
1 \text { day (2 hours) } \\
\text { One week after immediate post-tests }\end{array}$ \\
\hline Delayed Post-test & $\begin{array}{l}\text { Interpretation (sentence and discourse level) } \\
\text { Production (sentence level). Three weeks after re-exposure and four } \\
\text { weeks after the immediate post-tests }\end{array}$ \\
\hline
\end{tabular}

Fig. 1: Overview of the study

comparable amount of Japanese language (not containing the target feature) during the treatment phase. A pre-test and post-test procedure was adopted. The pre-tests were administered two days prior to the beginning of the instructional treatment period (see experiment overview in Figure 1). After the pre-tests were administered, participants were randomly assigned to groups: processing instruction and control groups. Tests consisted of a sentence-level interpretation and production tasks and one discourse-level interpretation task.

Immediate post-tests were used at the end of the first initial treatment. A delayed post-tests battery was administered to groups three weeks after the reexposure treatment. The processing instruction group and the first control group received two hours of instruction, but only the processing instruction group received the re-exposure treatment between the first post-test and the delayed post-test. The second control group received no instruction for the length of the all experiment. The instructor was the researcher and not the subjects' regular classroom instructor. The length of the treatment was constrained by the availability of the participants and the existing classroom arrangements. One-way ANOVAs were conducted on the raw scores for all pre-tests to assess whether there were any statistically significant differences among the two groups before 
the beginning of the experimental period. Repeated measures ANOVAs were used on pre- and post-test scores to assess whether there were any effects for instruction.

\subsection{Target linguistic feature}

The Japanese passive was the linguistic item chosen for this study because it is affected by the First Noun Principle. When L2 learners of Japanese parse sentences, they need to figure out who did what to whom. Normally L2 learners parse sentences relying on word order and employ a first noun processing strategy that assigns agent status to the first noun or pronoun they encounter in a sentence. English and Japanese have similar active and passive constructions. Tom hit Chris is an active sentence and is different in structure from Chris was hit by Tom.

(1) Tom hit Chris トムはクリスを打つ

(2) Chris was hit by Tom クリスはトムに見舞われた

Following the First Noun Principle (P2), L2 learners tend to misinterpret sentences like the passive structure (2) in Japanese by assigning the role of agent to the first noun or noun phrase in the sentence. They may therefore misinterpret the sentence (2) as Chris hit Tom. This processing strategy is thought to cause a delay in L2 learners' Japanese acquisition of this structure and word order pattern. Previous research within the input processing/processing framework has investigated the relative effects of processing instruction in altering the First Noun Principle and helping learners to correctly interpret and produce sentences containing the target feature (VanPatten and Cadierno,1993; VanPatten and Oikkenon 1996; VanPatten and Wong 2006; Morgan-Short and Bowden 2006; VanPatten, Inclezan, Salazar and Farley 2009). The overall findings are consistent in providing evidence for the positive effects of processing instruction.

\subsection{Materials}

One instructional packet for the Japanese passive structure was designed by Hikima (2011) and used in both studies. The packet was developed following the guidelines of processing instruction (Lee and VanPatten, 2003), which draws on the principles of VanPatten's input processing model (VanPatten, 1996, 2004). Processing instruction seeks to intervene in the processes learners use to get data from the input. During processing instruction training, learners never engage in 
production practice Thus, learners do not produce the form other than on the production pre-test and post-test. Processing instruction aims at teaching L2 learners how to interpret and comprehend the targeted structure in the input by making them use that structure to understand meaning.

The materials created for the processing instruction groups consisted of two components: explicit information and structured input activities. It contained highly frequent a familiar vocabulary for Japanese students in their second-year undergraduate degree. Learners in the processing instruction group were provided with explicit information of the grammatical target structure and were given information on processing strategies (First Noun Principle). The explicit information component described the use and characteristics of the passive structure in Japanese and, as importantly, provided information on the processing strategy that affects this structure. Sample materials are provided in Appendix 1. The explicit information was followed by structured input activities (twelve structured input activities were developed). In structured input activities learners come to interpret the meaning of the grammatical structure in the input. The structured input activities aimed at helping L2 learners correctly interpret this structure affected by the First Noun Principle, and they were developed to encourage L2 learners to focus their attention on the Japanese passive structure during comprehension. Learners were never asked to produce a sentence with the correct Japanese passive structure, but rather, engaged in processing input sentences so that they could parse elements in the sentence correctly and interpret the meaning of the sentence appropriately. The reason is that the target structure in a passive sentence, using a word order based processing strategy would be inappropriate. Structured input activities aimed at helping L2 learners to make a correct interpretation of this structure affected by the First Noun Principle. Care was taken to ensure that the practice items in this instructional packet did not allow students to rely on event probabilities (both nouns are capable of performing the action but one interpretation is more likely than another) to interpret input strings. The structured input activities used in the experiment were of two types: referential (six activities) and affective (six activities). Eight of those (four referential and four affective) were developed for the re-exposure treatment. The objective of the re-exposure treatment was to strengthen the learners' ability to process the target item. Learners first carried out the referential activities and then the affective activities. In the referential activities of the instructional packet, learners were required to process the input in order to establish the agent who performed the action of the verb. Referential activities have a correct answer. Each of our referential activities consisted of ten tokens, i.e., ten sentences. Participants received only limited feedback while completing the structured input activities. They were only told whether their interpretations were correct or not, but were 
not supplied with any other information. The affective activities, which each consisted of ten tokens, required participants to express their opinion or feelings based on the informational content of the input sentences. In these activities there was no right or wrong answer. The main purpose was to direct learner's attention to the target structure, but to also require that they had to process each item for meaning in order to successfully complete the task. The L2 learners who formed the control group received no instructional treatment on the targeted feature during the course of the experiment. An additional four referential and four affective structured input activities were developed for the re-exposure packet.

\subsection{Assessment tasks and scoring}

In order to evaluate the effectiveness of the processing instruction treatment on the acquisition of Japanese passive structure and to address the three research questions guiding this study, three different tests were developed: two sentencelevel assessments, one focused on interpretation and the other production; and one discourse-level assessment (presented the discourse as a dialogue). A sample of the tasks used is provided in Appendix 2 (see also Benati, Lee and Hikima 2010). Three versions of each of the three tests were created. The tests were counterbalanced across groups. One version as the pre-test and the other two versions as post-test and delayed post-test were used. The pre-tests and post-tests were equal in terms of length, the use of high-frequency vocabulary, and overall difficulty. This was tested through a number of pilot studies.

The interpretation sentence-level assessment was an aural task developed to measure knowledge gained by learners at interpreting passive forms in Japanese. This test consisted of twenty audio-taped sentences that were recorded by a native-speaker of Japanese speaking at a normal speed. Of the twenty items, ten were actual targets and the other ten distracters. The verbs used in these sentences were mostly regular and were chosen from two Japanese textbooks: Minna no nihongo (2007) and Japanese for busy people (2003). By referencing these textbooks we are certain that familiar vocabulary was used in constructing the sentences. The participants were required to listen to each sentence and to select one of two pictures that matched their interpretation. Learners had only one opportunity to hear and interpret a sentence. The two pictures differed in terms of who was performing the action. For the assessment task, learners also had the option of indicating that they were not sure who performed the action. Correct responses were given a score of 1 and each incorrect response a score of 0 . The maximum score on this test was 10 points and the minimum 0 . Distracters were not scored. 
The sentence-level written production task was developed to measure learner's ability to produce correct Japanese passive verb forms. The production assessment task consisted of twenty incomplete sentences in Japanese. They were given the agent (already marked appropriately in the passives) and object and had to provide the correct verb form. The learners were instructed to complete the sentences according to the English translation provided. Ten sentences were target items, i.e., passives, and the other ten were distracters that used the active voice. Measuring accuracy in producing correct passive forms in Japanese was the main goal of this test and so we scored only the ten sentences for which the English translation was a passive construction. Learners scored 1 point for each correct sentence produced and 0 points for incorrect ones (not using the correct verb ending -shita used for active sentences vs. -sareta used for passive sentences). The maximum possible score was 10 points and the minimum 0.

The discourse-level interpretation task was developed and used to measure the ability of learners to interpret correct Japanese passive forms when these forms are embedded in discourse. The task can be described as guided or prompted recall. The discourse-level interpretation task was presented to the learners as a dialogue. In this task, two people were talking to two characters in a book: Yoshiko chan and Kuma kun. Yoshiko chan is a girl and Kuma kun is a bear and both are main characters in a famous picture book (Hikima 2006). The verbs we used in this assessment task were selected from the verbs we had used in the sentence-level interpretation test. The construction of the dialogue is similar to the construction of the sentences. High-frequency lexical items and familiar vocabulary were used. To make the learners' task easier, the dialogue was divided into and presented to learners in four separate segments, each of which included passive and active sentences. The task was designed so that the target items were embedded in discourse, but at the same time were not buried in lengthy discourse. Wong (2010) used a similar procedure to administer discourse-level input. Two native speakers of Japanese recorded the dialogue using a normal rate of speech. The assessment instructions oriented the participants to listen for who did what. Each dialogue segment was played once; no repetition was provided so that we could measure real time comprehension. After participants heard the dialogue, they opened the task booklet to the appropriate answer sheet.

That is, they did not see the pictures while they heard the relevant dialogue segment. We created a different answer sheet for each dialogue segment and it formed its own page in the test booklet. Once they turned to the answer sheet they had to choose between two pictures that represented different actions in the dialogue. The only difference between the two pictures in each item was who was the agent and who was the patient of the action. However, if participants were not sure of the correct answer, they could tick the "I am not sure" option. We gave the 
learners 15 seconds to make their selections. Three of the segments contained two items, a target and a distracter, and one contained three items. Five passive forms served as target items for this test, and the other five were distracters that were not scored. The maximum possible score was 5 points and the minimum 0 .

\section{Results}

\subsection{Sentence-level interpretation data}

Table 1 provides the descriptive statistics for learners' performance on the sentence-level interpretation tasks. The descriptive statistics show the means of the three groups in the sentence-level interpretation test in the immediate posttest and delayed post-tests. A one-way ANOVA was conducted on the pre-test scores. The analysis showed no significant differences between the three groups before instruction $(F(2,54)=.603 p=.556)$.

Any differences found after instruction will be attributed to the effects of instruction. On the interpretation post-test, the PI group and the PI-R group, which also received processing instruction, improved between 50\% and 60\% from pre-test to immediate post-test. Both groups were better than the control group which made no improvements. The PI-R group improved over $25 \%$ further in the delayed post-test after the re-exposure treatment comparing to the PI group.

The $2 \times 3$ ANOVA showed a significant main effect for Time $(F(2,54)=55.034$, $p<.000)$; a significant main effect for Treatment $F(2,54)=83.627, p<.000$; and significant interaction between Treatment and Time $F(2,54)=93.955, p=.000$. Given the significant main effect for instructional treatment post hoc tests were conducted to compare the group's scores from the pre-test to the post-test. The test showed that the PI group and the PI-R group were significantly different than the Control group ( $p<.000$ and $p<.000$, respectively). There was no difference

Table 1: Descriptive statistics for sentence-level interpretation task

\begin{tabular}{|c|c|c|c|c|c|c|}
\hline \multirow[t]{2}{*}{ Groups } & \multicolumn{2}{|c|}{ Pre-test } & \multicolumn{2}{|c|}{ Post-test } & \multicolumn{2}{|c|}{ Delayed-Post-test } \\
\hline & $M$ & $S D$ & $M$ & $s$ & $M$ & $S D$ \\
\hline $\mathrm{PI}(n=20)$ & .444 & .527 & 6.41 & 1.05 & 8.67 & .500 \\
\hline $\mathrm{C} 1(n=17)$ & .725 & .744 & 5.75 & 1.03 & 5.12 & .755 \\
\hline C2 $(n=18)$ & .285 & .487 & .142 & .377 & .428 & .534 \\
\hline
\end{tabular}


between the PI group and the PI-R group $(p=.810)$. The difference in scores from the immediate post-test to the delayed post-test were also statistically significantly different. The PI group was significantly different than the PI-R group $(p<.001)$ and the control group $(p<.000)$. The PI-R group was significantly better than the control group which receive no instruction $(p<.004)$. These results demonstrate that only the processing instruction groups (PI and PI-R) gained in their ability to interpret Japanese passive constructions presented at the sentence-level. The control group made no gains. Processing instruction is clearly superior to the control group as the instructional treatment had a large impact in helping learners process and parse Japanese passive forms correctly. Re-exposure after the first post-test did lead to greater improvement on the sentence-level interpretation test for the PI-R group. The results revealed that re-exposure to the processing instruction treatment conveyed a positive effect on the processing instruction as learners from this group improved in their ability to process and parse the targeted form at interpretation sentence-level between the first posttest and the delayed posttest. The PI group did not receive re-exposure and although participants in this group retained their original gains from post-test 1 to the delayed post-test, they did not improve in the delayed post-test.

\subsection{Sentence-level production data}

The descriptive statistics presented in Table 2 show the large gains made by the PI and PI-R groups in the production sentence-level task ( $48 \%$ from pre-test to posttest) and the further improvement obtained by the PI-R groups in the delayed post-test (an additional 10\%). The control group made no improvements.

A one-way ANOVA on the pre-test scores obtained in the production task was carried out. The results revealed no significant difference between the groups' scores before instruction $(F(2,54)=2.238 p=.494)$. Therefore, we attribute any differences after administering the treatments to the effects of those treatments.

Table 2: Descriptive statistics for sentence-level production task

\begin{tabular}{|c|c|c|c|c|c|c|}
\hline \multirow[t]{2}{*}{ Groups } & \multicolumn{2}{|c|}{ Pre-test } & \multicolumn{2}{|c|}{ Post-test } & \multicolumn{2}{|c|}{ Delayed-Post-test } \\
\hline & $M$ & $S D$ & $M$ & $S$ & $M$ & $S D$ \\
\hline $\mathrm{PI}(n=20)$ & .333 & .500 & 4.88 & .78 & 5.87 & .726 \\
\hline $\mathrm{C} 1(n=17)$ & .500 & .755 & 4.87 & .640 & 4.12 & .640 \\
\hline $\mathrm{C} 2(n=18)$ & .142 & .377 & .285 & .487 & .714 & .309 \\
\hline
\end{tabular}


The results of the $2 \times 3$ ANOVA revealed, as in the case of the sentence-level interpretation task, a significant main effect for Time $F(2,54)=32.270, p<.001$. There was also a significant main effect for Treatment $F(2,54)=52.383, p<.001$; and significant interaction between Treatment and Time $F(2,54)=15.987, p<.001$. These results indicate that only the two processing instruction groups (PI and PI-R) improved significantly from pre-test to post-tests (immediate and delayed). The control group did not. A post hoc means comparison on the scores for the processing Instruction groups and the control group was performed. The test revealed no significant difference between the post-test scores of the two processing instruction groups $(p<.001)$. The difference in scores from the immediate post-test to the delayed post-test were also statistically significantly different. Both processing instruction groups were different to the control group $(p<.000$ for the PI group and $p<.003$ for PI-R group). The analysis revealed that the scores between the PI group and the PI-R group which received no re-exposure were significantly different $(p<.003)$. Once again, re-exposure after the first post-test did lead to greater improvement on the sentence-level production test. Processing instruction had a positive impact on learners' performance in the written production of correct passive forms in Japanese. After the additional processing instruction training, learners from the PI-R group made further improvement in their ability to produce sentences containing the targeted form.

\subsection{Guided recall of the dialogue-based discourse-level interpretation data}

Table 3 presents the descriptive statistics for learners' performance on the dialogue-based discourse-level interpretation test. A one-way ANOVA to compare pre-test scores for the three groups. The analysis revealed no significant difference between the groups' scores $(F(2,54)=.149 p=.709)$ before instruction. The processing instruction groups (PI and PI-R) improved around 45\% from

Table 3: Descriptive statistics for discourse-level interpretation task: dialogue version

\begin{tabular}{|c|c|c|c|c|c|c|}
\hline \multirow[t]{2}{*}{ Groups } & \multicolumn{2}{|c|}{ Pre-test } & \multicolumn{2}{|c|}{ Post-test } & \multicolumn{2}{|c|}{ Delayed-Post-test } \\
\hline & $M$ & $S D$ & $M$ & $s$ & $M$ & $S D$ \\
\hline $\mathrm{PI}(n=20)$ & .717 & .481 & 4.54 & .881 & 6.66 & 1.58 \\
\hline C1 $(n=17)$ & .250 & .462 & 4.50 & .925 & 4.18 & .834 \\
\hline C2 $(n=18)$ & .428 & .534 & .285 & .377 & .142 & .377 \\
\hline
\end{tabular}


pre-test to immediate post-test and the PI-R group made further improvements (20\%) in the delayed post-test, after receiving the additional training. The control group made no improvement but maintained the scores obtained after the first post-test.

The $2 \times 3$ ANOVA revealed a significant main effect for Time $F(2,54)=32.555$, $p<.001$; a significant main effect for Treatment $F(2,54)=13.000, p<.007$; and a significant interaction between Treatment and Time $F(2,54)=10.043, p<.001$. These results demonstrate that only the processing groups (both PI and PI-R) improved significantly from pre-test to post-tests. The control group did not. These results demonstrate that processing instruction resulted in significant knowledge gain. The processing instruction groups were superior to the control group in that the instructional treatment had a significant impact in helping students process and parse Japanese passive forms correctly when these forms are embedded in discourse. Post hoc means comparisons on the scores all groups was performed. The results confirmed that from the pre-test to the immediate post-test, the scores of the PI and PI-R groups are not significantly different $(p=.149)$. Both groups were better than the control group $(p<.000)$. The difference in scores from the first post-test to the delayed post-test were also statistically significantly different. The PI-R groups was statistically different than both the PI group which received no additional instruction $(p<.006)$ and the control group $(p<.000)$. The PI group was different than the control group who received no instruction throughout the experiment $(p<.004)$.

\subsection{Summary of findings}

The main findings support the three questions of the present study. The first question formulated in the present study was: Would learners receiving processing instruction improve in their ability to interpret and produce sentences containing Japanese passive forms? The data collected through the sentence-level tests (interpretation and production) clearly indicated that processing instruction has a positive effect in the way learners interpret and produce sentences containing the target feature. In the experiment, the processing instruction groups performed significantly better than the control group in both sentencelevel tests.

The second question of the present study was: Would learners receiving processing instruction improve in their ability to interpret Japanese passive forms embedded in discourse? This question was framed on Lee's hypothesis (2004: 319) that processing instruction will yield significant improvement on discourse-level interpretation tasks. Results indicated that the processing in- 
struction groups improved in their ability to interpret Japanese passive constructions at discourse-level (dialogue), while the control group made no gains.

The third question of the present study was: Would learners receiving reexposure to the processing instruction treatment between the immediate and the delayed post-tests further improve in their ability to interpret (sentence and discourse) and produce sentences containing Japanese passive forms? The statistical analysis revealed that the re-exposure treatment had a positive effect on the processing instruction group. The processing instruction group further improved from the first post-test to the delayed post-test. Learners from this group improved in the way they were able to interpret and produce sentences containing Japanese passive forms. The scores after re-exposure were higher for the discourse-level task as well. The statistical analysis of the data collected through the discourselevel task (dialogue) revealed that the processing instruction made statistically significant improvements from the immediate post-test to the delayed post-test. Learners from this group clearly benefitted from the re-exposure treatment. Re-exposure to processing instruction seems to be an effective instructional tool for improving performance.

\section{Discussion and conclusion}

The main goal of this study was to establish the possible enhancing effects of re-exposure to processing instruction on L2 learners' ability to interpret sentences and discourse and produce sentences containing Japanese passive forms. In the present study the passive construction in Japanese, which is affected by learners' use of the first noun strategy to assign the role of agent, was examined. Processing instruction research has consistently found that processing instruction significantly improves learners' interpretation and production of sentences containing the target form. The research on processing instruction has consistently shown that learners who receive this type of grammar instruction improve significantly in their interpretation and production of the target forms. Results from the present experiment clearly demonstrate the effectiveness of processing instruction on improving learners' ability to interpret and produce the targeted linguistic item chosen in this study. The results from this study clearly show that only L2 learners in the processing instruction group make further improvements from the immediate post-test to the delayed post-test after receiving further processing instruction training when performance was measured on the sentence-level and the discourse-level tasks. Re-exposure to the instructional treatment is effective at further improving learners' ability to interpret and produce sentences containing Japanese passive forms. The main findings from the current study are 
similar to the ones obtained by Leow (1998). They revealed that learners in the re-exposure group maintained and improved their performance from the immediate to the delayed-post-test. Repeated exposures to processing instruction might be the solution to help L2 learners not only to maintain the good effects of instruction in the short-term, but also to increase learners' performance in the long-term.

Lee (2004) hypothesized that the effects of processing instruction would be positively measured using discourse-level interpretation tasks. In the present study, learners were exposed to both passive and active constructions embedded in discourse and had to identify the agent of the action. As a result of receiving processing instruction (both groups), learners improved significantly from pretest to post-test in successfully identifying the agent. Their low scores on the pretests indicate that they relied extensively on an incorrect word order processing strategy explained by VanPatten $(2004,2007)$ as the First Noun Principle. Processing instruction had a positive impact in helping learners to process this structure accurately. In the exploration of discourse-level effects it was decided to present learners with discourse in a dialogue form. The discourse task was based on exposing learners to the target structure embedded in a dialogue between two different speakers. The findings demonstrated that processing instruction was successful in helping learners to interpret the target structure when it was embedded in discourse. Learners receiving the re-exposure treatment made further improvement in the interpretation discourse-level task. The findings from this study provide further support to the effects of processing instruction on interpretation discourse-level task and confirm Benati and Lee's (2008: 173) Discourse Hypothesis.

In terms of the primary aim of the present study, the results from this classroom experiment show clear effectiveness for the re-exposure treatment in processing instruction. Improvement in the sentence-level task was over $25 \%$ from the immediate post-test to the delayed post-test. Improvement in the sentencelevel production task was over 10\% from the immediate post-test to the delayed post-test. Improvement in the interpretation discourse-level task was over 20\% from the immediate post-test to the delayed post-test.

In terms of the secondary aim of this study, the findings from this classroom experiment have demonstrated the effects of processing instruction in a nonRomance language (Japanese) and on a word order based processing problem (Japanese passive constructions). Processing instruction was effective when measured at the sentence level and it was proved that it was also effective when measured at the discourse-level. Given the results obtained with the discourselevel interpretation task, it might be concluded that processing instruction has a significant impact on input processing. 
Despite the positive exposure and re-exposure results for processing instruction, it must be recognised that the primary limitation of the present study is the relatively small number of participants in the treatment groups. Future research on this topic must include a larger pool of participants. Future research could compare longer-term effects of re-exposure to processing instruction over a longer period and include both discourse-level interpretation and production tasks.

Acknowledgments: The author would like to thank Noriko Hikima for contributing to the development of some of the materials used in this study. This study is part of a project for which a grant has been received by the Sassakawa foundation. The author would like to thank two anonymous reviewers for their insightful comments.

\section{References}

Anderson, John. 1985. Cognitive psychology and its implications. New York: Freeman.

Association for Japanese Language Teaching. 2003. Japanese for busy people. Tokyo: Kodansha International Ltd.

Benati, Alessandro. 2001. A comparative study of the effects of processing instruction and output-based instruction on the acquisition of the Italian future tense. Language Teaching Research 5. 95-127.

Benati, Alessandro. 2004. The effects of structured input activities and explicit information on the acquisition of italian future tense. In Bill VanPatten (ed.), Processing instruction: Theory, research, and commentary, 207-226. Mahwah, NJ: Lawrence Erlbaum.

Benati, Alessandro \& Lee James. 2008. Grammar acquisition and processing instruction: Secondary and cumulative effects. Bristol, UK: Multilingual Matters.

Benati, Alessandro \& James Lee. 2010. Exploring the effects of Processing Instruction on Discourse-level interpretation tasks with English past tense. In Alessandro Benati \& James Lee (eds.), Processing instruction and discourse, 176-216. London: Continuum.

Benati, Alessandro, James Lee \& Noriko Hikima. 2010. Exploring the effects of Processing Instruction on Discourse-level Interpretation Tasks with the Japanese Passive Construction. In Alessandro Benati \& James Lee (eds.), Processing instruction and discourse, 148-177. London: Continuum.

Benati, Alessandro, James Lee \& Erin McNulty. 2010. Exploring the effects of Processing Instruction on a Discourse-level Guided Composition with the Spanish Subjunctive after the adverb Cuando. In Alessandro Benati \& James Lee (eds.), Processing instruction and discourse, 97-147. London: Continuum.

Cadierno, Teresa. 1995. Formal instruction from a processing perspective: an investigation into the Spanish past tense. The Modern Language Journal 79. 179-93.

Cheng, An. 2002. The effects of processing instruction on the acquisition of ser and estar. Hispania 85. 308-323. 
Cheng, An. 2004. Processing instruction and Spanish ser and estar: Forms with semanticaspectual value. In Bill VanPatten (ed.), Processing instruction: theory, research, and commentary, 119-141. Mahwah, NJ: Erlbaum.

DeKeyser, Robert, Rafael Salaberry, Peter Robinson \& Michael Harrington. 2002. What gets processed in processing instruction: A commentary on Bill VanPatten's "Processing instruction: An update". Language Learning 52. 805-823.

Farley, Andrew. 2001. The effects of processing instruction and meaning-based output instruction. Spanish Applied Linguistics, 5, 57-94.

Farley, Andrew. 2004. The relative effects of processing instruction and meaning-based output instruction. In Bill VanPatten (ed.), Processing Instruction: Theory, Research, and Commentary, 143-168. Mahwah, N): Erlbaum,.

Hikima, Noriko. 2006. We are Bilinguals. Nadaku Kobe, Japan: Taiseido Shobo.

Lee, James. 2004. On the generalizability, limits, and potential future directions of processing instruction research. In Bill VanPatten (ed.), Processing instruction: Theory, research, and commentary, 311-323. Mahwah, NJ: Erlbaum.

Lee, James \& Bill VanPatten. 2003. Making communicative language teaching happen ( $2^{\text {nd }}$ ed.). New York: McGraw-Hill.

Lee, James \& Alessandro Benati. 2007. Second Language Processing: An Analysis of Theory, Problems and Solutions. London: London: Continuum.

Lee, James \& Alessandro Benati. 2009. Research and Perspectives on Processing Instruction. New York: Mouton de Gruyter.

Minna no Nihongo Yasashii Sakubun. 2007. 3A Corporation.

Morgan-Short, Kara \& Harriet Bowden. 2006. Processing instruction and meaningful outputbased instruction: effects on second language development. Studies in Second Language Acquisition 28. 31-65.

Leow, Ronald. 1998. Effects of amount and type of exposure on adult learners' L2 deelopment in SLA. Modern Language Journal 82. 49-68.

Sanz, Cristina. 1997. Experimental tasks in SLA research: Amount of production, modality, memory, and production processes. In William Glass \& Teresa Pérez-Leroux (eds.), Contemporary perspectives on the acquisition of Spanish: Production, processing, and comprehension, 41-56. Somerville, MA: Cascadilla Press.

Sanz, Cristina. 2004. Computer delivered implicit versus explicit feedback in processing instruction. In Bill VanPatten (ed.), Processing instruction: Theory, research, and commentary, 241-255. Mahwah, N): Erlbaum.

VanPatten, Bill. 1996. Input processing and grammar instruction: theory and research. Norwood, NJ: Ablex.

VanPatten, Bill. (ed.). 2004. Processing instruction: Theory, research, and commentary. Mahwah, NJ: Erlbaum.

VanPatten, Bill. 2007. Input processing in adult second language acquisition. In Bill VanPatten \& Jessica Williams (eds.), Theories in second language acquisition, 115-135. Mahwah, NJ: Erlbaum.

VanPatten, Bill. forthcoming. Processing perspectives on instructed second language acquisition. In John Schwieter (eds.), The Cambridge Handbook of Bilingual Processing (pages forthcoming). Cambridge: Cambridge University Press.

VanPatten, Bill \& Teresa Cadierno. 1993. Explicit instruction and input processing. Studies in Second Language Acquisition 15. 225-243. 
VanPatten Bill \& Soile Oikennon. 1996. Explanation vs. structured input in processing instruction. Studies in Second Language Acquisition 18. 495-510.

VanPatten Bill \& Cristina Sanz. 1995. From input to output: Processing instruction and communicative tasks. In Fred Eckman, Dianne Highland, Peter Lee, Jean Mileham \& RitaWeber (eds.), Second Language Acquisition: Theory and Pedagogy, 168-185. Mahwah, NJ: Erlbaum.

VanPatten Bill \& Wynne Wong. 2004. Processing instruction and the French causative: Another replication. In Bill VanPatten (ed.), Processing Instruction: Theory, research, and commentary, 97-118. Mahwah, NJ: Erlbaum.

VanPatten Bill \& Claudia Fernández. 2004. The long-term effects of processing instruction'. In Bill VanPatten (ed.), Processing Instruction: Theory, Research, and Commentary, 273-289. Mahwah, NJ: Erlbaum.

White, Lydia, Nina Spada, Patsy Lightbown \& Leila Ranta. 1991. Input enhancement and L2 question formation. Applied Linguistics 12. 416-432.

\section{Appendix 1 (Sample Materials)}

Listen to each sentence and select a sentence that matches what you hear.

$1 \square$ Yoshiko ate Kuma's cake

$2 \square$ Yoshiko invited Kuma

$3 \square$ Yoshiko hit Kuma

$4 \square$ Yoshiko kissed Kuma

$5 \square$ Yoshiko called Kuma
Kuma ate Yoshiko's cake.

Kuma invited Yoshiko

Kuma hit Yoshiko

Kuma kissed Yoshiko

Kuma called Yoshiko.

Instructor's script

1 よしこちゃんはくま君にケーキを食べられました。Yoshiko’s cake was eaten by Kuma

2 よしこちゃんはくま君をさそいました。Yoshiko invited Kuma.

3 くま君はよしこちゃんにたたかれました。Kuma was hit by Yoshiko

4 くま君はよしこちゃんにキスされました。Kuma was kissed by Yoshiko.

5 よしこちゃんはくま君をよびました。Yoshiko called Kuma.

(the activity continues in a similar fashion)

\section{Appendix 2 (Sample Assessment Tasks)}

Partial sample of the sentence-level interpretation test 


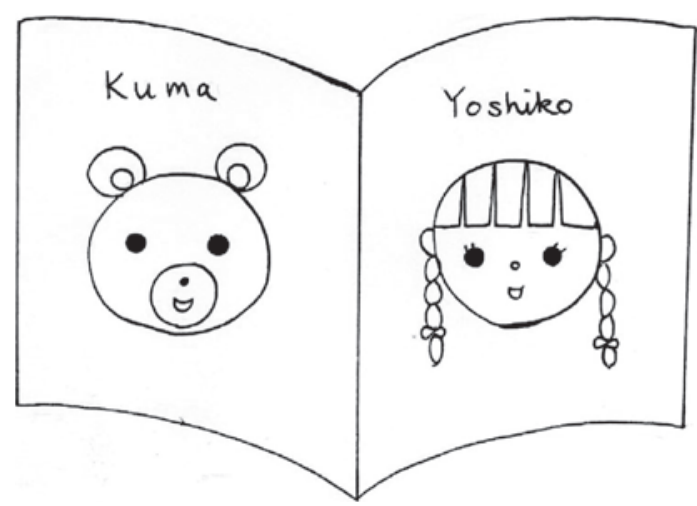

Listen to each sentence and then tick the picture that matches what you heard.

However, if you were not sure what heard, tick "I am not sure".

Name

II amot sure




\section{Instructor's script}

1 くま君はよしこちゃんにたのみました。Kuma asked Yoshiko

2 よしこちやんはくま君に 言われました。Yoshiko was told by Kuma

3 よしこちゃんはくま君を おこしました。Yoshiko woke Kuma up

Partial sample of the sentence-level production test

Complete each sentence according to the English translation.

1 Yoshiko was hit by Kuma

よしこちゃんはくまくんに

2 Kuma said toYoshiko

くまくんはよしこちゃんに

3 Yoshiko's biscuit was eaten by Kuma

よしこちゃんはくまくんにビスケットを

4 Kuma scolded Yoshiko

くまくんはよしこちゃんを

5 Yoshiko woke Kuma up

よしこちゃんはくまくんを

Partial sample of the discourse-level interpretation task (dialogue)

Two people are talking about a book describing Yoshiko and Kuma.

When listening to the dialogue, you must focus on who did each action. Listen to the dialogue and remember who did what. After listening, open the answer sheet and then tick the picture that matches what you heard.

\section{Attention!}

You can't open the answer sheet before listening to the dialogue.

You can't look at the answer sheet while you are listening to the dialogue. 


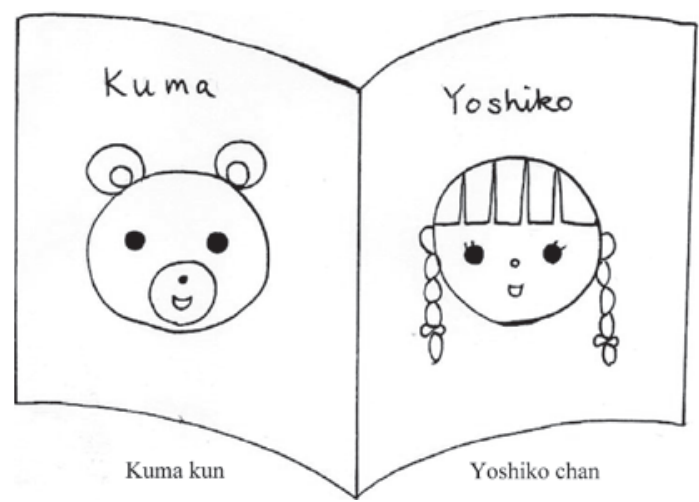

Name

Answer sheet 1: Who did each action? Tick the picture that matches what you heard.

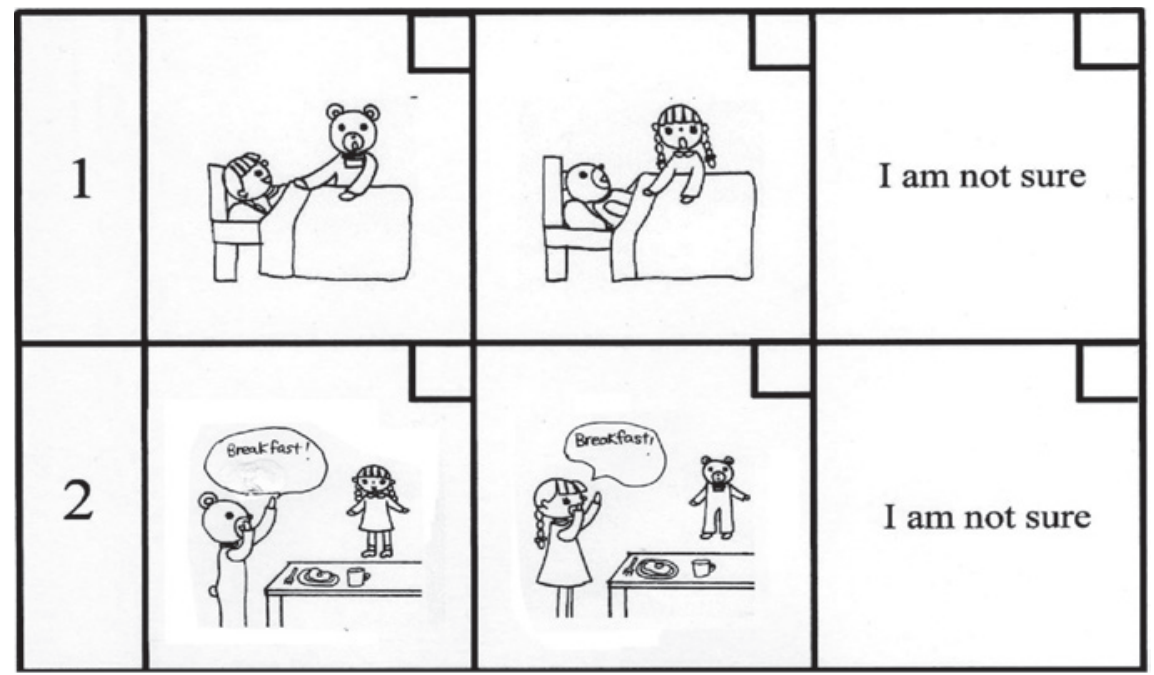

Please do not turn the page until after you hear the next part of the dialogue.

Instructor's script

\section{Answer sheet 1}

田中：よしこちゃんとくまくんの本を読みました。おもしろかったですよ。 鈴木：どんな話ですか。 
田中：朝です。くまくんはよしこちゃんを起こしました。 1

「朝ごはんできたよ。」とくまくんはよしこちゃんに呼ばれました。(1) 鈴木：いつも二人は一緒ですね。

\section{Answer sheet 2}

田中：朝ごはんの後、

よしこちゃんはくまくんに暇かどうか聞かれました。

二人はケーキを焼くことにしました。

鈴木：そしてどうなりましたか。

田中：くまくんはよしこちゃんにほめられました。(3)

鈴木：なぜですか。

田中：上手にケーキを焼いたからです。

\section{Answer sheet 3}

田中：よしこちゃんはくまくんに一緒に食べようと言いました。 2

鈴木：それで?

田中：よしこちゃんはくまくんのケーキを食べました。 3

そしてよしこちやんはくまくんにミルクを飲まれました。(4)

\section{Answer sheet 4}

鈴木：その後どうなりましたか。

田中：喧嘩になりました。

よしこちゃんはくまくんにコップをこわされました。(5)

そしてよしこちやんはくまくんをたたきました。 4

でも最後になかよくなりました。

くまくんはよしこちゃんにキスしました。 5

鈴木：楽しい話ですね。

\section{Translation}

\section{Answer sheet 1}

Tanaka: I read a picture book written about Yoshiko and Kuma. It was interesting. Suzuki: How about the story?

Tanaka: In the morning, Kuma woke Yoshiko up. ......

"Breakfast is ready!" Kuma was called by Yoshiko. ......

Suzuki: They are always together aren't they?

\section{Answer sheet 2}

Tanaka: After breakfast,

Yoshiko was asked by Kuma whether Yoshiko was free or not. ......

They decided to bake a cake. 
Suzuki: What happened then?

Tanaka: Kuma was complimented by Yoshiko. .......

Suzuki: Why?

Tanaka: The cake was good.

\section{Answer sheet 3}

Tanaka: Yoshiko said "let's have a cake" to Kuma. ......

Suzuki: Then?

Tanaka: Yoshiko ate Kuma's cake. ....... active 3 and Yoshiko's milk was drunk by Kuma. ......

\section{Answer sheet 4}

Suzuki: What happened later?

Tanaka: They began to fight.

Yoshiko's cup was broken by Kuma. ......

then Yoshiko hit Kuma. ...... active 4

However, they finally made up.

Kuma kissed Yoshiko. ....... active 5

Suzuki: It is an interesting story isn't it? 